\title{
ВЛИЯНИЕ 9-БЕНЗИЛ-2-БИФЕНИЛИМИДАЗО[ I ,2-А] БЕНЗИМИДАЗОЛА НА ВНУТРИГЛАЗНОЕ ДАВЛЕНИЕ
}

\author{
Л.В. Науменко', А.С. Таран', О.Н. Жуковская² \\ ${ }^{1}$ Кафедра фармакологии и биоинформатики, ВолгГМУ, \\ 400131, Россия, Волгоград, Павших Борцов, 1. \\ 2Лаборатория органического синтеза, НИИ ФОХ ЮФУ, \\ 344090, Россия, Ростов-на-Дону, Стачки, 194/2.
}

DOI: 10.19163/MedChemRussia2021-2021-91

E-mail:milanaumenko@mail.ru

Имидазо[ I ,2-а]бензимидазол - трициклическая конденсированная система, производные которой проявляют широкий спектр биологической активности. К настоящему времени выявлено более 50 их видов, при этом установлено, что введение в положение 2 гетероцикла арильных заместителей (фенил- или замещённый фенил-) резко усиливает некоторые виды активностей, например, гипотензивную и антиаритмическую. С целью расширения объектов исследования и установления роли бифенила, который является весьма эффективным фармакофором, получен ранее неизвестный имидазо[ I ,2-а]бензимидазол, содержащий 4-бифенильную группу в положении 2 и бензильный фрагмент у атома азота N9 (см. схему).

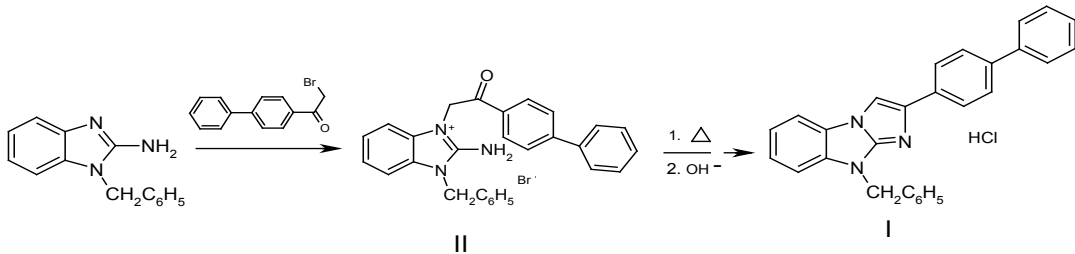

При взаимодействии 1-бензил-2-аминобензимидазола с 4-фенилфенацилбромидом образуется четвертичная соль (II), циклизация которой приводит к 9-бензил-2-бифенилимидазо[І,2-а]бензимидазолу (I). Присутствие в молекуле этого соединения двух «привилегированных» [1] фрагментов-имидазобензимидазольного и бифенильного - должно способствовать мультитаргетному действию. Фармакологические исследования показали, что у животных с экспериментальным сахарным диабетом (СД) внутриглазное давление выше в 1,5 раза по сравнению с интактной группой, а исследуемое соединение, вводимое перорально в дозе 12,5 мг/кг животным с СД, приводит к статистически значимому снижению изучаемого показателя относительно опытной группы СД.

Синтез и изучение структуры соединения выполнены О.Н. Жуковской

при финансовой поддержке Министерства образования и науки РФ в рамках Госзадания № БАЗ 0110/20-3-11ИХ (ЮФУ).

\section{Литература}

[1] R. DeSimone, K. Currie, S. Mitchell, J. Darrow, D. Pippin, Comb. Chem. High Throughput Screen.,2004, 7, 473.

$$
-91-
$$

